УДК 616.12-007.2-053.2-07:618.33

\title{
Пренатальна діагностика та хірургічне лікування судинних кілець
}

\author{
Павлова А. О. ${ }^{1}$, Куркевич А. К. ${ }^{1}$, Руденко Н. М. ${ }^{1,2}$, Емець Р. М. ${ }^{1}$, \\ Таммо Раад ${ }^{1}$, Дацко О. М. ${ }^{1}$ \\ ${ }^{1}$ ДУ «Науково-практичний медичний центр дитячої кардіології та кардіохірургії МОЗ України» (Київ) \\ ${ }^{2}$ Національна медична академія післядипломної освіти імені П. Л. Шупика (Київ)
}

\begin{abstract}
Судинні кільця (СК) - це група вроджених аномалій судин системи дуги аорти (ДА), які стискають трахею і стравохід, що в свою чергу спричиняє респіраторні симптоми або проблеми з ковтанням. 32012 по 2015 р. у ДУ «НПМЦДКК МОЗ України» під час пренатальної ЕхоКГ діагноз СК було встановлено у 28 випадках. Первинне обстеження вагітних проводилося з 20 тижня гестації (т. г.) до 38 т. г. Під час пренатальної ЕхоКГ з 28 випадків СК у 24 було запідозрено правосторонню дугу аорти з лівосторонньою артеріальною протокою та аберантною лівою підключичною артерією (ПрДА, ЛАП, АЛПА), у 4 - подвійну дугу аорти (ПДА). Із 28 плодів у 20 (71,4\%) випадках СК було ізольованим, у 8 (28,6\%) - поєднаним з іншими вродженими вадами серця (ВВС). Діагноз СК було знято у 3 (10\%) випадках за допомогою ЕхоКГ (1 - пренатально, 2 - постнатально). Двоє дітей померли після народження від позасерцевих причин. Усього в Центрі було проконсультовано 23 дитини з СК: у 17 (73,9\%) випадках було проведено КТ і підтверджено діагноз СК (100\%). Проте при аналізі анатомічних варіантів СК повне підтвердження пренатальний діагноз дістав у 11 $(64,71 \%)$ випадках, а частковий незбіг - у $6(35,29 \%)$. У $6(26,1 \%)$ випадках із 23 через добре самопочуття пацієнтів і відсутність симптоматики КТ заплановано у старшому віці. Хірургічне лікування СК було проведено у $13(56,52 \%)$ пацієнтів.

На основі даних літератури та проведеного аналізу власних результатів можна зробити висновок, що КТ залишається золотим стандартом у діагностиці судинних аномалій, проте пренатальна ЕхоКГ дозволяє виявити СК ще під час вагітності, що дає можливість організувати необхідні додаткові діагностичні та лікувальні заходи і підвищити якість надання допомоги пацієнтам із даною ВВС.
\end{abstract}

Ключові слові: судинні кільия, ехокардіографія, пренатальна діагностика, комп'ютерна томографія.

Судинні кільця (СК) - це група вроджених аномалій судин системи дуги аорти (ДА). Основною особливістю СК є те, що судинні структури повністю оточують трахею і стравохід. У частині випадків це призводить до стиснення цих структур, що в свою чергу спричиняє респіраторні симптоми або проблеми з ковтанням [1]. Залежно від ступеня стиснення стравоходу та трахеї може виникнути клінічна симптоматика - від важкої дихальної недостатності, яка потребуватиме невідкладних втручань одразу після народження, до легкого перебігу з поступовим наростанням симптомів аж до появи трахеомаляції в більш старшому віці [2]. Пренатальна діагностика СК є актуальною в обох випадках, оскільки при значному стисненні це визначатиме перинатальну тактику з невідкладним хірургічним лікуванням. У другому випадку, при невираженому здавлюванні трахеї та стравоходу, пренатальна діагностика $\epsilon$ тим методом, який може виявляти дану групу вроджених вад, оскільки запідозрити та діагностувати СК у постнатальному періоді значно важче.

Згідно з даними літератури, СК становлять менше $1 \%$ усіх вроджених аномалій серцево-судинної системи. Проте ця цифра може бути занижена, оскільки да- на вада у багатьох випадках протікає безсимптомно або симптоми не пов'язують з аномалією ДА $[1,3]$.

Інколи СК можуть бути поєднані з іншими вродженими вадами розвитку, зокрема конотрункальними вадами серця (тетрадою Фалло (ТФ), транспозицією великих артерій (ТВА), спільним артеріальним стовбуром (САC)) і генетичними синдромами, включаючи делецію 22q11 хромосоми. Поширеність вади не залежить від статі та етнічних або географічних чинників $[1,3]$.

Мета роботи - провести аналіз власних результатів ефективності пренатальної діагностики СК та її впливу на хірургічне лікування.

Матеріали та методи. 32004 по 2015 р. у ДУ «НПМЦДКК МОЗ України» проведено 3708 первинних ехокардіографій (ЕхоКГ) плода. Всі обстеження проводились методом трансабдомінальної ЕхоКГ плода на ультразвукових сканерах Philips Sonos 7500, Siemens Acuson Sequoia 512 та Philips iU22 за допомогою конвексних датчиків частотою 5-1 МГц. 32012 по 2015 р. діагноз СК було встановлено у $28(0,7 \%)$ випадках. У 2012 році було діагностовано $3(10,7 \%)$ випадки, у $2013-2(7,1 \%)$, у $2014-11(39,3 \%)$, у $2015-$ 
12 (42,9\%) випадків. Вагітні направлялись у наш Центр з різних регіонів України: з Київської області було направлено 8 вагітних (з них 7 - з Києва), з Житомирської області - 6, з Чернігівської - 3, з Вінницької та Дніпропетровської - по 2 вагітних, із Запорізької, Львівської, Одеської, Полтавської, Рівненської, Черкаської, Чернівецької - по 1 вагітній.

Первинне обстеження проводилося з 20 тижня гестації (т. г.) до 38 т. г. Середній термін гестації при первинному обстеженні становив 26 тижнів (від 20 до 38 т. г.). До 22 т. г. діагностика проводилась у $12(42,86 \%)$ випадках, після - у $16(57,14 \%)$. У $15(53,57 \%)$ випадках вагітність була першою. Якщо первинне обстеження проводилося з 20 по 29 т. г. вагітній рекомендувалася повторна ЕхоКГ у терміні 33-34 т. г., якщо після 30 т. г. - повторна консультація, як правило, не призначалась. Усім вагітним було рекомендовано консультування дітей у Центрі до 1 місяця після народження. На момент першої консультації дітей із пренатально діагностованими СК оцінювалася наявність клінічних симптомів стиснення трахеї та стравоходу, проводилась експертна трансторакальна ЕхоКГ на ультразвуковому сканеpi Philips iU33 за допомогою секторних датчиків частотою 12-4 та 8-3 МГц. Комп’ютерна томографія (KT) після народження проводилася на 16-зрізовому томографі Siemens Somatom Sensation.

Результати та обговорення. Під час пренатальної ЕхоКГ з 28 випадків СК у $24(85,7 \%)$ було запідозрено правосторонню дугу аорти з лівосторонньою артеріальною протокою та аберантною лівою підключичною артерією (ПрДА, ЛАП, АЛПА), у 4 (14,3\%) - подвійну дугу аорти (ПДА). Із 28 плодів у $20(71,4 \%)$ СК було ізольованим, у $8(28,6 \%)$ - поєднаним з іншими вродженими вадами серця (ВВС). Із 24 плодів з діагнозом ПрДА, ЛАП, АЛПА у 18 (75\%) СК було ізольованим, у 6 (25\%) - поєднаним з іншими вродженими вадами серця (ВВС). В одному випадку було діагностовано кориговану транспозицію великих артерій з дефектом міжшлуночкової перегородки і атрезією легеневої артерії I типу (КТВА, ДМШП, АЛА I), у 4 випадках - дефект міжшлуночкової перегородки (ДМШП) (в одному з яких - із додатковою лівою верхньою порожнистою веною (ЛВПВ), що дренувалась у коронарний синус (KC)), і в одному - ЛВПВ дренувалася в КС).

Із 4 випадків ПДА у 2 СК було ізольованим, у 2 - поєднувалося з ВВС (1 ДМШП, 1 ЛВПВ, що дренувалась у КС). В одному випадку ізольованої ПДА через недостатню візуалізацію було проведено повторну ЕхоКГ плода, на якій було знято діагноз СК та діагностовано декстрапозицію серця і зміщення магістральних судин вправо внаслідок агенезії правої легені, що було підтверджено після народження методом КТ.

Одні пологи відбулись передчасно - на 28 т. г. $з$ летальним наслідком на 10-ій добі життя. В результаті інших вагітностей народилося 26 дітей. Термін гестації на момент пологів у середньому становив 38 т. г. (від 32 до 41 т. г.). У Києві відбулось 13 (50\%) пологів. Одна дитина померла на 5-ту добу життя від позасерцевої причини, проте на патологоанатомічному розтині було підтверджено діагноз правосторонньої дуги аорти. Медіана віку дітей на момент першої консультації становила 7 днів (від однієї доби до 120 днів). Усім пацієнтам було проведено трансторакальну ЕхоКГ, під час якої у 2 випадках було знято діагноз СК, що склало 7,6\% усіх народжених. У першому (при КТВА, ДМШП, АЛА I тип, ПрДА) ліва підключична артерія (ЛПА) відходила типово від брахіоцефального стовбура (БС) і під час ЕхоКГ чітко візуалізувалося його галуження, що в подальшому було підтверджено на КТ. У другому випадку функціонувала недіагностована єдина ліва верхня порожниста вена і було візуалізовано лівосторонню дугу аорти (ЛДА) з чітким галуженням БС.

Клінічні симптоми, такі, як стридор, кашель та порушення ковтання, спостерігались у $13(56,5 \%)$ із 23 випадків. У 17 (73,9\%) випадках було проведено КТ i діагноз СК було підтверджено (100\%). Проте при аналізі анатомічних варіантів CK повне підтвердження пренатальний діагноз дістав у $11(64,7 \%)$ випадках ПрДА, ЛАП, АЛПА, а частковий незбіг було зафіксовано в $6(35,3 \%):$ у 2 випадках пренатального діагнозу ПДА на КТ було змінено на ПрДА, ЛАП, АЛПА; у 3 випадках ПрДА, ЛАП, АЛПА - на ПДА; в 1 випадку ПрДА, ЛАП, АЛПА - на огинаючу дугу аорти (ОДА). В $6(26,1 \%)$ випадках із 23 через добре самопочуття пацієнтів і відсутність симптоматики КТ заплановано у старшому віці.

Хірургічне лікування ВВС було проведено у 13 (56,5\%) пацієнтів із 23. Із 9 випадків ПрДА, ЛАП, АЛПА один пацієнт був прооперований в іншій лікувальній установі. Із 8 випадків ізольованої ПрДА, ЛАП, АЛПА у 6 (75\%) корекція вади здійснювалася через лівобічну задньо-бокову м'язовозберігаючу торакотомію по III-IV міжребер'ю, у 2 (25\%) - через серединну стернотомію внаслідок необхідності закриття ДМШП. Реімплантацію АЛПА було здійснено у 4 (50\%) випадках.

У 3 випадках ПДА домінуючою була ПрДА, тому здійснювалось пересічення ЛДА з лівобічної задньобокової м'язовозберігаючої торакотомії по III-IV міжребер'ю у 2 випадках ізольованого СK, із серединної стернотомії - в одному випадку при ДМШП. В одному випадку ОДА було проведено радикальну корекцію (uncrossing aorta procedure) із закриттям ДМШП.

Згідно з даними світової літератури, СК - це ВBC, яка потребує своєчасної діагностики та хірургічної корекції, оскільки тривала компресія трахеї з часом призводить до некурабельної трахеомаляції зі 
збереженням клініки навіть після лікування [1-3]. Пренатальна ЕхоКГ надає широкі можливості для діагностики та лікування СК. Оскільки діагноз встановлюється ще під час вагітності (особливо важливою $є$ рання діагностика - до 22 т. г.), батьки отримують змогу пройти генетичне консультування, визначитись зі спеціалізованим пологовим будинком, де відбудеться розродження, та лікувальною установою, де дитина зможе своєчасно отримати весь комплекс діагностичних і лікувальних заходів. Опубліковано кілька робіт, які доводять можливість пренатальної діагностики СК [4-6]. Основною проблемою залишається діагностика анатомічного варіанту судинного кільця і ступеня стиснення трахеї та стравоходу [7]. Постнатальна ЕхоКГ і натепер є малоінформативною при диференціальній діагностиці різних анатомічних варіантів судинних кілець, проте дозволяє з високою точністю виключити супутні ВВС.

Висновки. На основі даних літератури та проведеного аналізу власних результатів можна зробити висновок, що КТ залишається золотим стандартом у діагностиці судинних аномалій, проте пренатальна ЕхоКГ дозволяє виявити СК під час вагітності, що дає можливість організувати необхідні додаткові діагностичні та лікувальні заходи і підвищити якість надання допомоги пацієнтам із цією ВВС.

\section{Література}

1. Vascular rings / Backer C. L., Mongŭ M. C., Popescu A. R. et al. // Semin Pediatr Surg. - 2016 Jun. - Vol. 25 (3). P. 165-75. doi: 10.1053/j.sempedsurg.2016.02.009. Epub 2016 Feb 22.

2. Congenital vascular rings: a clinical challenge for the pediatrician / Licari A., Manca E., Rispoli G. A. et al. // Pediatr. Pulmonol. - 2015. - Vol. 50. - P. 511.

3. Vascular Ring Diagnosis and Management: Notable Trends Over 25 Years / Evans W. N., Acherman R. J., Ciccolo M. L. et al. // World J Pediatr Congenit Heart Surg. - 2016 Nov. - Vol. 7 (6). - P. 717-720.

4. Prenatal Sonographic Features of a Double Aortic Arch: Literature Review and Perinatal Management / Trobo D., Bravo C., Alvarez T. et al. // J Ultrasound Med. 2015 Nov. - Vol. 34 (11). - P. 1921-7. doi: 10.7863/ ultra.14.12076. Epub 2015 Oct 7.

5. Fetuses with right aortic arch: a multicenter cohort study and meta-analysis / D'Antonio F., Khalil A., Zidere V. et al. // Ultrasound Obstet Gynecol. - 2016 Apr. - Vol. 47 (4). P. 423-32. doi: 10.1002/uog.15805. Epub 2016 Mar 16.

6. Prenatal diagnosis of vascular rings / Jain S., Kleiner B., Moon-Grady A. et al. // J Ultrasound Med. - 2010 Feb. Vol. 29 (2). - P. 287-94.

7. Prenatal diagnosis and outcome of right aortic arch without significant intracardiac anomaly / Razon Y., Berant M., Fogelman R. et al. // J Am Soc Echocardiogr. - 2014 Dec. - Vol. 27 (12). - P. 1352-8.

\title{
Prenatal diagnosis and surgical treatment of vascular rings
}

\author{
Pavlova A. ${ }^{1}$, Kurkevich A. ${ }^{1}$, Rudenko N. ${ }^{1,2}$, Yemec R. ${ }^{1}$, Tamo Raad ${ }^{1}$, Datsko O. ${ }^{1}$ \\ ${ }^{1}$ Ukrainian Children's Cardiac Center (Kyiv) \\ ${ }^{2}$ Shupyk National Medical Academy of Postgraduate Education (Kyiv)
}

\begin{abstract}
Vascular rings (VR) are a group of congenital anomalies of the vessels of the aortic arch (AA) that compress the trachea and the esophagus. It causes respiratory symptoms or problems with swallowing. In the period from 2012 to 2015 we diagnosed 28 cases of VR. The primary examination of pregnant women was conducted from the 20th to the 38th weeks of gestation. Right aortic arch with left ductus arteriosus and aberrant left subclavian artery (RAA, LDA, ALSA) was diagnosed in 24 cases. The double aortic arch (DAA) was diagnosed in 4 cases. Among the 28 diagnosis the VR was isolated in 20 and associated with other structural congenital heart disease (CHD) in 8 cases. The diagnosis of VR was took after 1 prenatal and 2 postnatal echocardiograms in 3 cases off. Two children died after birth from non-cardiac causes. Among the 23 diagnoseis the VR was confirmed on the computed tomography angiography (CTA) in 17 (73.9\%) cases. However, the different anatomical variants of the VR was complete confirmed in $11(64,71 \%)$ cases and a partial discrepancy was found in $6(35,29 \%)$ cases. Six $(26,1 \%)$ patients had no symptoms, therefore CT was postponed. Surgical treatment of VR was performed in 13 (56.52\%) patients. Articles and own analysis show that CT is the best method in diagnostics VR, but prenatal echocardiography can detect VR during pregnancy. It makes possible to make important additional examinations and helps to improve the treatment.
\end{abstract}

Key words: vascular rings, echocardiography, prenatal diagnosis, computer tomography.

\section{Пренатальная диагностика и хирургическое лечение сосудистых колец}

\author{
Павлова А. А. ${ }^{1}$, Куркевич А. К. ${ }^{1}$, Руденко Н. Н. ${ }^{1,2}$, Емец Р. М. ${ }^{1}$, Таммо Раад ${ }^{1}$, Дацко А. М. ${ }^{1}$
}

${ }^{1}$ ГУ «Научно-практический медицинский центр детской кардиологии и кардиохирургии МЗ Украины» (Киев)

${ }^{2}$ Национальная медицинская академия последипломного образования имени П. Л. Шупика (Киев)

Сосудистые кольца (СК) - это группа врожденных аномалий сосудов системы дуги аорты (ДА), которые окружают трахею и пищевод, что в свою очередь вызывает респираторные симптомы или проблемы глотания. С 2012 по 2015 г. в ГУ «НПМЦДКК МЗ Украины» во время пренатальной ЭхоКГ диагноз СК был выставлен в 28 случаях. 
Первичное обследование беременных проводилось с 20 недели гестации (н. г.) до 38 н. г. Во время пренатальной ЭхоКГ в 24 из 28 случаев СК была заподозрена правосторонняя дуга аорты с левосторонним артериальным протоком и аберрантной левой подключичной артерией (ПрДА, ЛАП, АЛПА), в 4 - двойная дуга аорты (ДДА). У 20 из 28 плодов СК было изолированным, в 8 - комбинированным с другими врожденными пороками сердца (ВПС). Диагноз СК был снят в 3 (10\%) случаях с помощью ЭхоКГ (1 - пренатально, 2 - постнатально). Двое детей умерли после рождения от внесердечных причин. Всего в Центре было проконсультировано 23 ребенка с диагнозом CK, из них в 17 (73,9\%) случаях было проведено КТ и подтвержден диагноз СК (100\%). Однако при анализе анатомических вариантов СК полное подтверждение пренатальный диагноз получил в $11(64,71 \%)$ случаях, а частичное несовпадение зафиксировано в $6(35,29 \%)$. В $6(26,1 \%)$ случаях из 23 в связи с хорошим самочувствием пациентов и отсутствием симптоматики КТ запланировано в старшем возрасте. Хирургическое лечение СК было проведено у $13(56,52 \%)$ пациентов.

На основании данных литературы и проведенного анализа собственных результатов можно сделать вывод, что КТ остается золотым стандартом в диагностике сосудистых аномалий, однако пренатальная ЭхоКГ позволяет выявить эту патологию еще во время беременности, что дает возможность организовать необходимые дополнительные диагностические и лечебные мероприятия и повысить качество оказания помощи пациентам с данным ВПС.

Ключевые слова: сосудистые кольца, эхокардиография, пренатальная диагностика, компьютерная томография. 